\title{
ANALISIS KOLABORASI PADA PENGEMBANGAN KEMITRAAN USAHATANI MANGGA DI KABUPATEN MAJALENGKA
}

\author{
Sri Ayu Andayani ${ }^{1)}$, Lies Sulistyowati ${ }^{2)}$, Siti Nur Azisah ${ }^{2)}$ \\ 1) Fakultas Pertanian Universitas Majalengka, \\ 2) Departemen Sosial Ekonomi Pertanian Fakultas Pertanian Universitas Padjadjaran \\ Email: sri.ayuandayani@yahoo.com
}

\begin{abstract}
ABSTRAK
Jawa Barat merupakan salah satu sentra mangga di Indonesia dan Kabupaten Majalengka termasuk di dalamnya. Potensinya cukup besar, namun belum didukung dengan kemitraan yang berkelanjutan. Melalui kemitraan diharapkan dapat meningkatkan kualitas, kuantitas dan kontinuitas pasokan. Pada kenyataanya, kemitraan yang terjadi belum memberikan kepastian pasar dan kepercayaan antar pihak yang terlibat. Penelitian ini bertujuan mengkaji kolaborasi dalam kemitraan mangga dan memberikan upaya dalam mengatasi konflik yang terjadi. Informan dalam penelitian ini terdiri dari petani mangga dan PD.Dunia Buah (bandar besar). Penelitian menggunakan metode kualitatif dengan teknik studi kasus dan teknik analisis deskriptif dengan bantuan alat analisis model teori drama. Hasil penelitian menunjukkan bahwa kolaborasi antar pelaku kemitraan mangga belum terlaksana dengan baik, karena masing-masing pelaku belum dapat berperan sesuai fungsinya masing-masing, sehingga konflik dan dilema masih terjadi. Kemitraan masih diwarnai konflik, dilema dan ancaman, terutama terkait standar kualitas, tenggang waktu pembayaran dan bantuan modal. Melalui kerangka pikir bersama (petani mangga dengan perusahaan mitra), maka dihasilkan resolusi/kesepakatan untuk keberlanjutan kemitraan. Dengan demikian, masing-masing pihak tidak merasa dirugikan (terutama menyangkut kepastian pasar), sehingga akan memotivasi petani dalam meningkatkan produksi.
\end{abstract}

Kata kunci: Mangga, kemitraan, teori drama

\begin{abstract}
West Java is one of the centers of mango in Indonesia and Majalengka regency including one mango production centers in West Java. Majalengka sizeable potential can not be supported by partnerships berkelanjutan.Kemitraan which should bridge the gap between producers and markets in the hope of improving the quality, quantity and continuity of supply of mango. Partnerships happened yet provide market certainty and trust between the parties involved so that conflicts and dilemmas. This study examines the collaboration that took place in partnership mango and provide countermeasures for conflict situations. Informants in this study is the mango farmers, PD.Dunia Fruit as a big city. Method of research done through qualitative method with case study research techniques. Data analysis using descriptive analysis with the aid of a theoretical model analysis drama. The results showed that collaborative partnerships between actors mango has not done well in which conflicts and dilemmas still happen because each actor can not act according to their respective functions. In partnership there are conflicts and dilemmas and threats related to quality standards, delayed payment and capital assistance. Through the joint between the frame of mango farmers with a partner company, the resulting resolution/agreement for the continuation of the partnership so that both parties do not feel disadvantaged, especially regarding the market certainty that will motivate farmers to increase the production of mango.
\end{abstract}

Keywords: Mango, partnerships, drama theory

\section{PENDAHULUAN}

Mangga merupakan salah satu komoditi yang bernilai ekonomis dan strategis (Deptan, 2007). Mangga dapat dikatakan sebagai salah satu jenis buah yang banyak digemari oleh masyarakat dan mempunyai kandungan gizi yang tinggi. Provinsi Jawa Barat menduduki posisi kedua sebagai sentra produksi mangga setelah Jawa Timur (Dinas Pertanian, 2012). Kabupaten Majalengka termasuk salah satu sentra produksi mangga di Jawa Barat.

Permintaan mangga terus meningkat, baik dari pasar domestik maupun internasional. Namun demikian, produksi mangga pada tahun 
2010 mengalami penurunan akibat hujan yang terus menerus. Penurunan produksi terus berlanjut hingga tahun 2013 (Dinas Pertanian Jawa Barat, 2015). Pengembangan agribisnis mangga masih banyak kendalanya diantaranya yaitu belum terwujudnya ragam, kualitas, kesinambungan pasokan dan kuantitas sesuai dinamika permintaan pasar, ketimpangan penguasaan ilmu pengetahuan dan teknologi, aset utama lahan, modal, dan akses pasar (Saptana, 2007).

Hafsah (2003) menegaskan bahwa untuk mengatasi kendala yang dihadapi oleh petani terutama dalam menangani permodalan, produksi, dan pemasaran, maka dilaksanakan program kemitraan yang merupakan suatu strategi bisnis yang dilakukan oleh dua pihak atau lebih dalam jangka waktu tertentu untuk meraih keuntungan bersama dengan prinsip saling membutuhkan, saling memperkuat.

Kemitraan antara berbagai pelaku ekonomi diharapkan dapat menciptakan sistem ekonomi yang efektif dan efisien, namun kenyataannya hubungan kemitraan yang terjadi belum sesuai dengan konsep kemitraan. Keuntungan hanya dapat diperoleh oleh perusahaan mitra sementara posisi petani tetap lemah. Berdasarkan dari permasalahan ini dalam usaha pengembangan mangga dan peran kemitraan pada agribisnis mangga maka peneliti termotivasi untuk melakukan penelitian tentang bagaimana kolaborasi antara pelaku pada rantai pasok kemitraan yang terjadi pada pengembangan usaha agribisnis mangga dan upaya pengembangan kemitraan yang dapat dilaksanakan pada usahatani mangga di Kabupaten Majalengka sehingga ada alternatif model kemitraan yang menguntungkan kedua belah pihak.

\section{METODE PENELITIAN}

Obyek penelitian ini adalah gambaran kolaborasi pelaku dan upaya pengembangan kemitraan pada rantai pasok usaha pengembangan agribisnis mangga di Kabupaten Majalengka. Penelitian yang didesain secara kualitatif dengan menggunakan metode studi kasus ini ditujukan untuk menggali informasi yang mendalam dari berbagai pelaku (informan) yang terlibat dalam kemitraan agribisnis mangga, baik petani maupun bandar. Data yang diperoleh melalui FGD (focus Group Discussion) dianalisis dengan Metode Deskriptif dan Teori Drama.

\section{HASIL DAN PEMBAHASAN}

\section{Kolaborasi Antar Pelaku Pada Rantai Pasok Mangga}

Pelaku yang terlibat dalam rantai pasok mangga adalah industri pendukung yaitu penyedia input atau penangkar benih mangga, penjual agroinput lainnya seperti toko saprotan yang menyediakan semua kebutuhan petani dalam berusahatani mangga. Dinas Pertanian serta Dinas Perdagangan dan Perindustrian, perbankan dan lembaga keuangan lainnya. Di sentra produksi, pelaku yang terlibat dalam rantai pasok mangga adalah petani, bandar, kelompok tani, pemasok, pengumpul, pasar tradisional, perusahaan/eksportir, pengolah dan supermarket yang menyalurkan mangga sehingga sampai ke tangan konsumen.

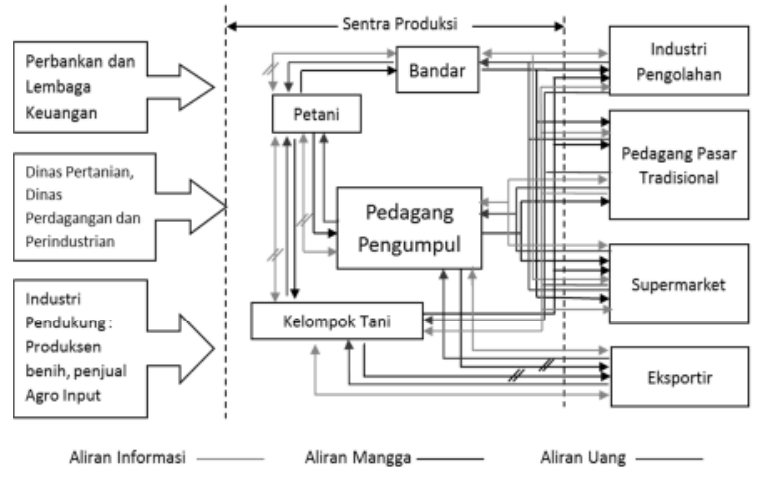

Gambar 1. Rantai Pasok Mangga

Terlihat pada Gambar 1, masing-masing pelaku yang terlibat memiliki aktivitas yang berbeda. Jaringan rantai pasok mangga di Kabupaten Majalengka banyak melalui bandar. Pemasaran yang dilakukan oleh bandar adalah mangga untuk memenuhi pasar tradisonal, supermarket. Industri pengolahan masih sangat kecil kurang dari 5 persen begitu pula dengan supermarket masih kecil.

Kegiatan sortasi dan grading dilakukan oleh bandar untuk tujuan pasar dan pembayaran ada yang secara tunai dari bandar ke petani atau menunggu karena bandar banyak yang mengalami tunda pembayaran biasanya sampai 21 hari dari supermarket maupun pasar tradisional. Informasi harga pada umumnya petani mudah untuk mengetahui namun untuk informasi pasar tujuan dari mangganya kurang mengetahui.

Permasalahan utama pengembangan mangga adalah keterbatasan pasar, dimana tidak semua pasar bisa ditembus, apalagi pada saat panen raya. Jumlah mangga di pasaran sangat 
banyak sehingga harga yang diterima petani menjadi sangat rendah, hal ini sesuai dengan hukum permintaan dan penawaran (Pyndick and Rubienfeld, 2008).

PD. Dunia Buah merupakan salah satu pedagang besar yang pernah menjalin kerjasama dengan eksportir yaitu PT.Indopres pada tahun 2005, tetapi kerjasama ini sudah tidak terjalin lagi dikarenakan adanya isu kandungan pestisida yang tinggi sehingga Indofresh menghentikan kerjasamanya. Begitu pula kerjasama yang terjadi dengan eksportir CV.Sumber Buah (SAE) masih bersifat non formal, tidak ada perjanjian yang mengikat sehingga tidak ada hak dan kewajiban. Melihat kondisi ini, diharapkan ada kemitraan yang mampu menampung hasil produksi mangga sehingga pelaku yang terlibat pada pengusahaan mangga tidak lagi dihadapkan dengan permasalahan pemasaran mangga.

Kelompok tani mangga sudah terbentuk di Kabupaten Majalengka. Para petani anggota mengharapkan adanya jaminan harga dan pasar ketika tergabung dalam kelompok tani. Namun kenyataannya, kelompok tani tidak mampu menampung semua produksi mangga yang dihasilkan petani, sehingga anggota kelompok tani tetap menjual mangganya masing-masing. Terlihat pada Gambar di atas, adanya aliran uang ketika bandar ataupun kelompok tani melakukan pembayaran ke petani tetapi ada juga petani yang meminjam modal terlebih dahulu untuk biaya usahataninya.

Aliran informasi pada rantai pasok mangga seharusnya terjalin secara dua arah, namun pada kenyataannya petani selalu menjadi pihak yang paling dirugikan. Dinamika harga dapat diketahui oleh petani, namun perkembangan pasar untuk tujuan mangganya tidak banyak diketahui oleh petani, karena tidak ada kontrak yang jelas antara petani dengan bandar, kelompok tani ataupun pedagang. Hal ini memerlukan kemitraan yang jelas sehingga adanya kepastian jaminan harga dan pasar. Dinas Pertanian (melalui penyuluh) dan Dinas Perdagangan dan Perindustrian belum secara optimal menyampaikan informasi-informasi yang dibutuhkan oleh petani dan pelaku mangga pada umumnya. Perbankan juga belum dapat memfasilitasi akses permodalan dan informasi permodalan yang dibutuhkan petani mangga.

\section{Pendekatan Teori Drama Pada Kemitraan Mangga}

Dilema dalam kemitraan. Secara riil, teridentifikasi dua dilema dalam kemitraan, yakni dilema konfrontasi dan dilema kolaborasi. Dilema konfrontasi meliputi dilema ancaman dan dilema penolakan. Dilema ancaman terjadi saat ada pihak yang tidak menanggapi secara serius ancaman dari pihak lainnya. Dalam hal ini dilakukan oleh petani dan bandar besar penyalur mangga ke perusahaan yaitu PD.Dunia Buah. Petani sering diberikan bantuan sarana produksi, tetapi pada saat panen petani sering pula menjual mangganya kepada pihak lain.

PD.Dunia buah secara lisan memberikan ancaman kepada petani dan petani selalu tidak menanggapinya karena petani mencari harga yang sesuai dengan keinginannya sementara harga dari PD.Dunia Buah selalu tidak sesuai serta petani merasa tidak ada kontrak kerjasama yang jelas antar kedua pihak. Sedangkan dilema penolakan merupakan dilema yang terjadi karena terdapat pihak yang sulit meyakinkan pihak lainnya untuk menyetujui keinginan salah satu pihak (Bryant, 2004). Pada kasus ini PD.Dunia Buah sebagai bandar menginginkan adanya kontrak kerjasama dengan petani mangga terutama dalam pemasaran, namun hal ini belum dapat diterima oleh petani dengan alasan tidak mau terikat kontrak sehingga petani bebas menjual mangganya kemana pun.

Dilema kolaborasi meliputi dilema percaya dan dilema kerjasama. Terkait dengan dilema percaya PD.Dunia Buah dengan petani mangga belum ada kepercayaan diantara keduanya. PD.Dunia Buah merasa petani selalu menutupi jumlah hasil produksinya serta harga yang petani dapatkan dari penjualan bandar lain, sedangkan petani pun tidak percaya kepada PD.Dunia Buah dalam proses pembayaran termasuk penetapan harga mangga, lamanya proses pembayaran dan pengembalian produk. Dengan demikian petani merasa belum ingin melakukan kontrak kerjasama. Sedangkan dilema kerjasama ini terjadi pada petani mangga yang sering tertarik untuk menjual mangganya ke bandar lain. Adanya penawaran harga yang lebih tinggi, proses pembayaran yang langsung tunai membuat petani lebih memilih menjual mangga ke pihak lain walaupun sebelumnya telah diberikan bantuan oleh PD.Dunia Buah.

\section{Tahap Awal}

Kerangka Pikir Petani. Berdasarkan hasil penelitian, diperoleh kerangka pikir petani mangga untuk mendapatkan posisi ideal bagi 
kepentingannya seperti terlihat pada Gambar 2. Permasalahan yang seringkali dihadapi oleh petani mangga adalah pada teknik budidaya. Teknologi budidaya off season yang disarankan Dinas Pertanian masih sulit dilaksanakan terkait dengan pengetahuan dan keterampilan petani sehingga perlu adanya pelatihan dan pembinaan dari Dinas terkait.

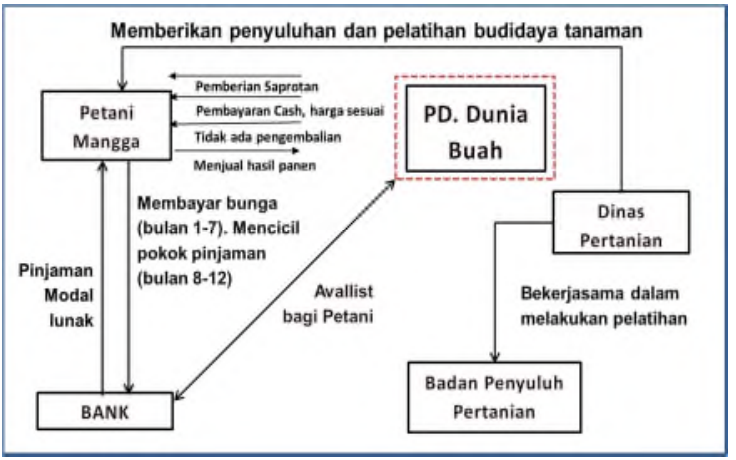

Gambar 2. Kerangka Pikir Petani Mangga

Permasalahan lainnya yaitu permodalan. Petani seringkali diberi bantuan berupa sarana produksi oleh PD.Dunia Buah tetapi secara kuantitas belum dapat memenuhi kebutuhan dari usahataninya. Terkait kekurangan modal untuk proses produksi mangga, perbankan pun belum mampu memfasilitasinya. Para petani menilai persyaratannya terlalu memberatkan. Petani berharap jika kemitraan terjalin dengan PD.Dunia Buah, perusahaan mau mnejadi avalist atau penanggung kredit petani terhadap lembaga keuangan. Petani berharap pula PD.Dunia Buah membeli produk mangga dengan harga yang tinggi dengan membayar secara tunai, memberi pinjaman berupa sarana produksi, serta mangga yang dikirimkan tidak mengalami reject.

\section{Kerangka Pikir PD.Dunia Buah}

(PD.DB). PD.DB memiliki kerangka pikir yang terstruktur dalam mencapai posisi idealnya seperti terlihat pada Gambar 3. Permasalahan yang dihadapi oleh PD.DB adalah kepastian pasar. Setelah kandasnya kerjasama yg pernah dilakukan dengan eksportir PT. Indopres pada tahun 2005, sampai sekarang belum ada jalinan kerjasama lagi dengan perusahaan lain. PD.DB berharap pemerintah melalui Dinas terkait dapat memfasilitasi kemitraan dengan pasar lain. PD.DB menginginkan adanya kerjasama yang jelas dengan petani mangga dengan harapan petani memberikan kontinuitas pasokan dan memiliki kewajiban untuk menjual mangganya kepada PD.DB. PD.DB akan memfasilitasi penyediaan sarana produksi yang terpusat sehingga akan membuat toko saprotan dengan harga pabrik.

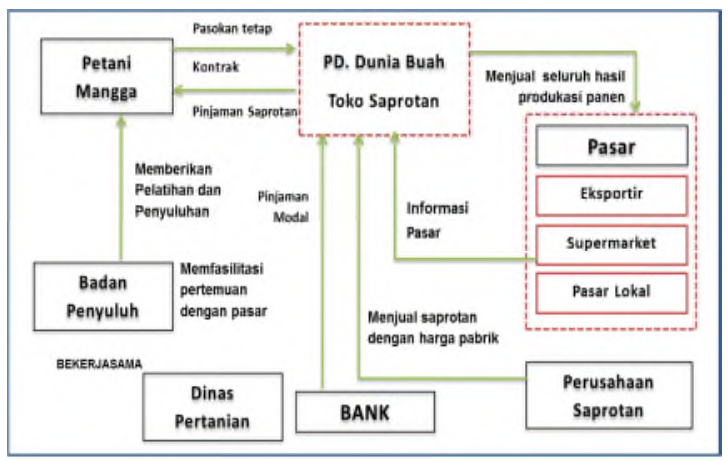

Gambar 3. Kerangka Pikir PD.Dunia Buah

\section{Tahap Pembentukan (Kerangka Bersama) Penyelenggaraan Kontrak Kerjasama}

Kemitraan. Hubungan petani mangga dengan PD.Dunia Buah sudah berlangsung lama namun belum terikat kontrak kerjasama yang jelas secara tertulis sehingga petani masih menjual mangganya kepada bandar lain (Gambar 4).

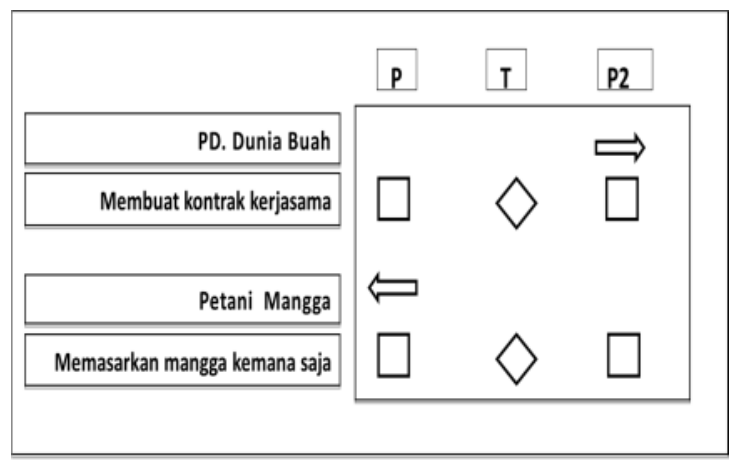

Gambar 4. Situasi Konflik tentang Penyelenggaraan Kontrak Kerjasama

Gambar 4, menjelaskan skema konflik antara petani mangga dengan PD.Dunia Buah dengan menggunakan perangkat lunak Confrontation Manager. Kontrak kerjasama ini diperlukan baik oleh petani maupun PD.Dunia Buah. Hal ini dikarenakan PD.Dunia Buah memerlukan kontinuitas pasokan sehingga dapat dipercaya oleh pasar, begitu pula petani mangga tidak mau produksinya melimpah sementara bandar tidak dapat menerimanya sehingga mangga petani tidak mengalami penumpukan yang mengakibatkan kerugian. PD Dunia Buah menjanjikan kepastian pasar sehingga petani nyaman dalam menjalani kontrak.

Petani akhirnya sepakat untuk mencoba melakukan kontrak kerjasama dengan PD. DB dan memberikan penawaran mengenai harga 
dan mengenai bantuan akses pinjaman modal seperti menjadi avalist bagi petani untuk perbankan. PD.DB menyetujui tentang negosiasi harga selama harga yang diajukan petani tidak jauh berbeda dengan harga pasar pada umumnya sehingga hal ini dapat dipertimbangkan oleh PD.DB. PD.DB pun memerlukan akses pinjaman modal dari perbankan untuk dapat membeli mangga dari petani secara tunai.

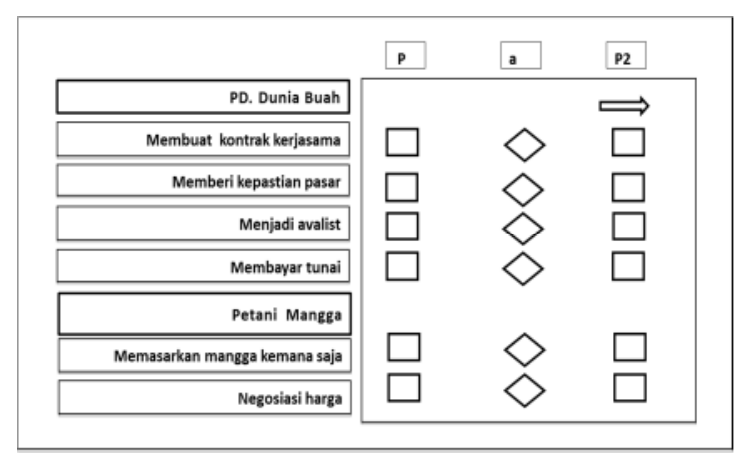

Gambar 5. Kerangka Pikir Bersama tentang Penyelenggaraan Kontrak Kerjasama

\section{Pengembalian Produk (Reject)}

Proses sortasi dan grading dilakukan di perusahaan, tetapi seringkali produk mengalami kerusakan akibat benturan pada saat proses pengangkutan. Ini menyebabkan ada proses rejected dan dikembalikan kepada petani. Kejadian reject ini tidak disetujui oleh petani jika nanti kontrak terjadi karena anggapan petani PD.DB tidak menjamin pasar. Di bawah ini ada Gambar 6 yang merupakan gambaran situasi konflik pada permasalahan penerapan pengembalian produk (reject).

Gambar 6 tersebut menjelaskan bahwa pihak PD.DB berpendapat tidak seluruh mangga yang dihasilkan petani diterima pasar maka akan berdampak pada pengembalian mangga oleh PD.DB kepada petani. Sebaliknya jika PD.DB melakukan reject kepada petani, maka petani akan mengakhiri kontrak kerjasamanya dengan PD.DB. Melalui berbagai pertimbangan, maka akhirnya mangga petani akan diterima seluruhnya tetapi dengan catatan PD.DB berhak atas penentuan harga mangga yang tidak lolos dalam proses sortasi dan grading.

Berdasarkan keinginan-keinginan yang telah diungkapkan petani mangga dan PD.DB maka diperoleh kerangka bersama (Gambar 7).

Simbol a menandakkan agreement yang terlihat pada gambar matriks di atas. Hal ini menunjukkan telah tercapainya persetujuan antar pihak-pihak yang terkait atas solusi dengan menerima seluruh produk mangga dari petani. Akan tetapi PD.DB berhak atas penentuan harga produk rejected. Dalam hal ini petani kembali menjadi penerima harga.

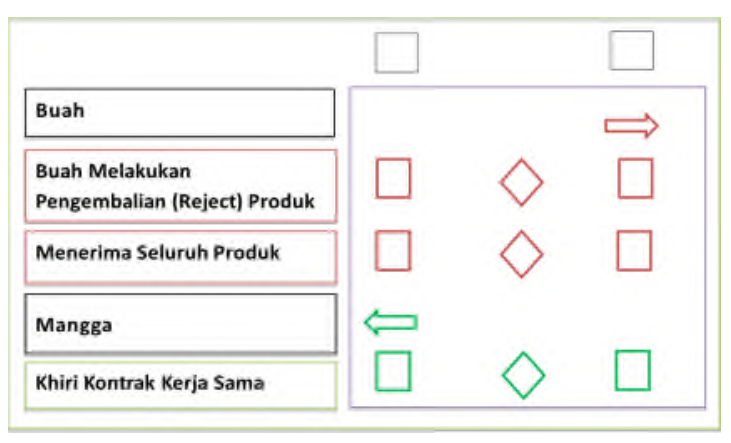

Gambar 6. Situasi Konflik tentang Reject Produk

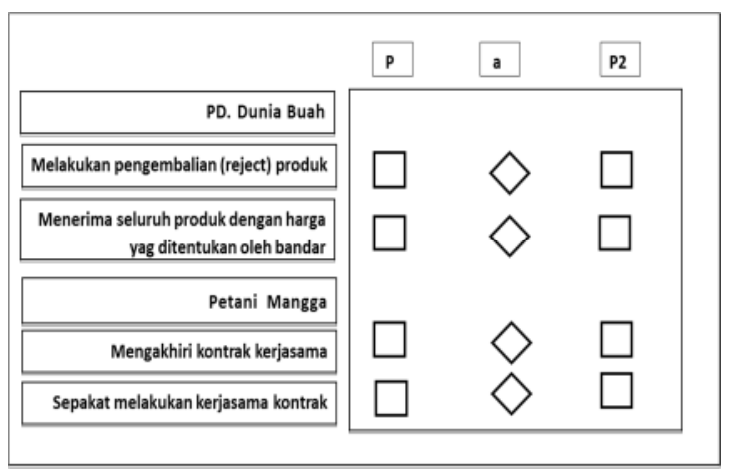

Gambar 7. Kerangka Pikir Bersama tentang Reject Produk

\section{Sanksi}

Kemitraan yang ideal terbangun apabila kedua pihak saling terbuka dan mempunyai kepercayaan. Sebelumnya PD.DB telah melakukan kerjasama dengan para petani mangga walaupun tidak secara tertulis, namun para petani banyak yang melakukan pelanggaran. PD.DB jika menjalin kemitraan maka akan menerapkan sanksi pada petani mangga yang melanggar. Berikut ini terlihat pada Gamabar 8 tawaran serta ancaman dari masing-masing pelaku. Matriks di atas menjelaskan bahwa petani mengancam akan berhenti bermitra jika PD.DB berhenti memberikan bantuan modal kepada petani, tetapi PD.DB memandang sangat perlu memberikan ancaman atau sanksi kepada petani walaupun PD.DB tidak ingin petani mangga mengakhiri kontrak kemitraan.

PD.DB mempertimbangkan kembali bentuk sanksi yang lebih ringan yaitu sanksi bertahap dengan melalui tahapan berupa teguran terlebih dahulu kemudian surat peringatan. Jika 
sanksi bertahap tetap dilanggar oleh petani maka PD.DB akan tegas tidak memberikan modal dan mengakhiri kontrak kemitraan dengan petani mangga. Tawaran ini disetujui oleh petani mangga seperti terlihat pada Gambar 9.

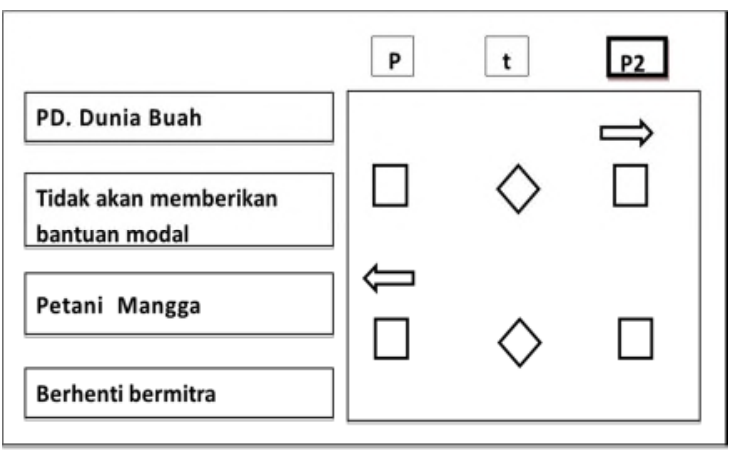

Gambar 8. Situasi Konflik tentang Sanksi Kesepakatan

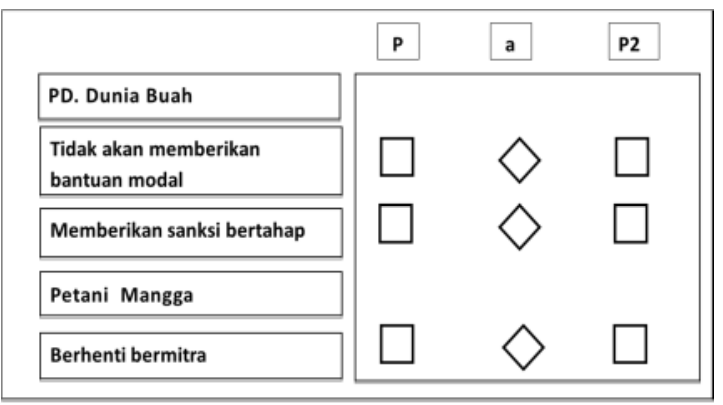

Gambar 9. Kerangka Pikir Bersama tentang Sanksi Kesepakatan

Perlakuan sanksi harus diimbangi dengan peningkatan kesadaran para petani mangga untuk membangun kepercayaan mitra sehingga menghasilkan kemitraan yang kontinyu. Dengan demikian perlu adanya pembinaan pihak pemerintah berupa pelatihan-pelatihan yang dapat membentuk karakter petani dalam meningkatkan komitmen kontrak kemitraan. PD.Dunia Buah sebagai Toko Saprotan

Para petani mangga menginginkan adanya pengadaan saprotan secara terpusat dengan akses yang mudah, karena selama ini petani mendapatkan bantuan modal berupa saprotan, tetapi tidak mencukupi dalam satu kali musim produksi mangga. PD.Dunia Buah disarankan menjadi toko saprotan yang bisa dibayar secara kredit oleh petani mangga, sehingga adaptif dengan musim panen.

\section{Kerangka Pikir Bersama}

Berdasarkan penggabungan kerangka pikir PD.Dunia Buah dengan kerangka berpikir petani mangga, maka terbentuk resolusi yang memberikan keadilan (win-win solution) untuk semua pihak (stakeholders) dan semua pelaku dalam kemitraan mangga. Tabel 1 berikut ini menjelaskan ringkasan posisi-posisi yang ditawarkan dan dapat disepakati bersama oleh masing-masing pelaku dan atau pihak-pihak yang terkait dalam kemitraan mangga. Ininya, diperlukan keadilan dalam kemitraan, terutama terkait dengan harga dan pasar. Diperlukan kesepakatan harga yang adaptif dan disepakati.

Kerangka pikir bersama merupakan hasil penggabungan kerangka pikir PD.Dunia Buah dengan petani mangga. Pada proses pembentukan kerangka pikir bersama terdapat penawaran yang diterima, dimodifikasi bahkan ditolak oleh salah satu pihak. Pada akhirnya ada upaya untuk menyatukan hal-hal yang bertentangan dari para pelaku kemitraan dan kemudian adanya kesepakatan. Berikut ini bagan kerangka pikir bersama yang telah disisipi resolusi kesepakatan kedua belah pihak.

Tabel 1. Analisis Kemitraan Ideal di Kabupaten Majalengka

\begin{tabular}{llll}
\hline \multirow{2}{*}{ Penawaran } & \multicolumn{2}{l}{ Posisi yang ditawarkan } & \multirow{2}{*}{ Resolusi } \\
\cline { 2 - 3 } & $\begin{array}{l}\text { PD.Dunia } \\
\text { Buah }\end{array}$ & $\begin{array}{l}\text { Petani } \\
\text { Mangga }\end{array}$ & \\
\hline Penyelengg & Melakukan & Tidak & Melakukan
\end{tabular}

araan kontrak melakukan kontrak dengan

kontrak secara kontrak kesepakatan kerjasama tertulis $\quad$ PD.Dunia Buah kemitraan memberikan kepastian pasar dan melakukan pembayaran secara tunai dengan harga hasil negosiasi dengan petani

\begin{tabular}{|c|c|c|}
\hline $\begin{array}{l}\text { Reject } \\
\text { produk }\end{array}$ & $\begin{array}{ll}\text { Melakukan } & \text { Tidak ada } \\
\text { reject } \text { produk reject } & \text { produk }\end{array}$ & $\begin{array}{l}\text { Tidak dilakukan } \\
\text { reject produk } \\
\text { namun } \\
\text { penentuan harga } \\
\text { produk reject } \\
\text { sepenuhnya hak } \\
\text { PD.Dunia Buah }\end{array}$ \\
\hline sanksi & $\begin{array}{l}\text { Sanksi tegas } \text { Tidak ada } \\
\text { yang sanksi } \\
\text { membuat jer، } \\
\text { petani }\end{array}$ & $\begin{array}{l}\text { Sanksi bertahap } \\
\text { sesuai dengan } \\
\text { banyaknya } \\
\text { pelanggaran } \\
\end{array}$ \\
\hline $\begin{array}{l}\text { PD.Dunia } \\
\text { Buah } \\
\text { sebagai } \\
\text { Toko } \\
\text { Saprotan }\end{array}$ & setuju & $\begin{array}{l}\text { PD }>\text { DB } \\
\text { menjual } \\
\text { saprotan dan } \\
\text { memberikan } \\
\text { kredit kepada } \\
\text { petani } \\
\end{array}$ \\
\hline
\end{tabular}

Gambar 10 menjelaskan kerangka pikir bersama yang dapat membentuk kemitraan dengan win-win solution dengan diawali dari 
pembentukan kontrak kerjasama antara $\mathrm{PD}>\mathrm{DB}$ dengan petani mangga di Kabupaten

Majalengka juga PD>DB berperan sebagai toko saprotan yang memberikan secara kredit kepada petani. Kontrak yang akan dijalankan oleh kedua belah pihak menerapkan PD>DB mendapatkan seluruh hasil produksi mangga dari petani dengan harga hasil negosiasi bersama dan dibayar tunai kepada petani. PD>DB juga akan memberikan kepastian pasar tetapi hal ini perlu ada campur tangan dari pihak pemerintah untuk memfasilitasi $\mathrm{PD}>\mathrm{DB}$ dengan pasar.

Kerangka bersama ini merupakan rekomendasi penulis dalam memperbaiki mekanisme kemitraan yang dijalankan berdasarkan tawaran dan posisi dari setiap pelaku kemitraan yang terlibat. Kerangka pikir bersama ini jika dapat diaplikasikan maka akan berlanjut pada tahap akhir yaitu tahapan tidak ada lagi konflik, dilema dan ancaman dalam kemitraan sehingga episode drama berakhir.

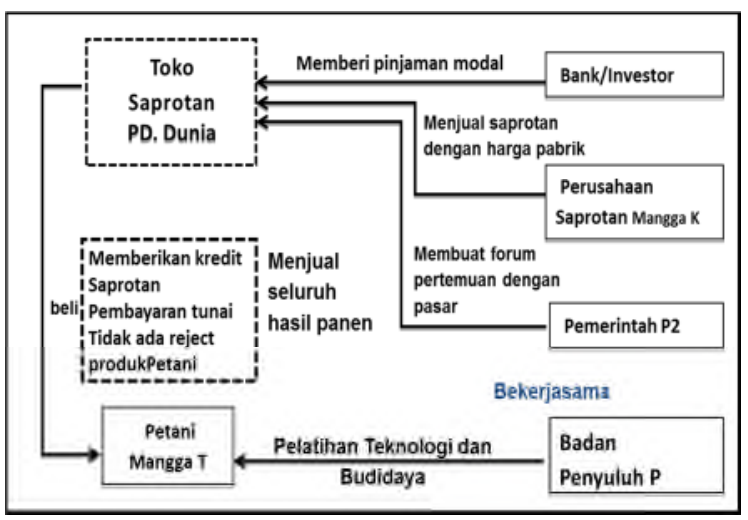

Gambar 10. Kerangka Pikir Bersama (Petani dan $\mathrm{PD}>\mathrm{DB})$

\section{KESIMPULAN}

Kolaborasi antar pelaku pada kemitraan usahatani mangga di Kabupaten Majalengka belum terlaksana dengan baik hal ini terlihat pada masing-masing pelaku yang terlibat belum berperan sesuai fungsinya. Dalam kemitraan petani mangga terdapat konflik dan dilema yang disebabkan oleh perbedaan tujuan masingmasing pihak. Dengan kerangka pikir bersama antara petani mangga dengan perusahaan mitra akhirnya menghasilkan resolusi/kesepakatan sebagai berikut: a) tidak adanya reject lagi sehingga semua mangga dapat diterima perusahaan mitra, b) harga mangga reject ditentukan oleh perusahaan mitra, c) standar kualitas tetap berlaku, d) pembayaran dari pihak mitra 3 hari setelah penyerahan mangga.
Masing-masing pihak yang bermitra diharapkan memiliki dan saling berkomitmen pada kesepakatan yang telah disetujui bersama sehingga tidak ada pihak yang merasa dirugikan serta kemitraan dapat berlangsung kontinyu. Diperlukan pendampingan dalam pelaksanaan kemitraan mangga yang berkelanjutan baik dari pihak pemerintah, Perguruan Tinggi, serta lembaga lainnya yang terkait.

\section{DAFTAR PUSTAKA}

Alviany, Yulia. 2014. Analisis Manajemen Risiko Usahatani Mangga di Kabupaten Indramayu Jawa Barat. Bogor: Institut Pertanian Bogor.

Boediono, Wayan Koster. 2002. Teori dan Aplikasi Statistika dan Probabilita, Bandung: Remaja Rosdakarya.

Bryant, J and Darwin (2004). "Exploring Interorganizational relationship in the health service: an immersive drama approach"

Dharma S. 2004. Manajemen Kinerja; Falsafah, Teori dan penerapannya. Jakarat:

Direktorat Jenderal Pendidikan Tinggi Departemen PendidikanNasional.

Deptan. 2007. Peraturan Menteri Pertanian No 273/kpts/OT.160/4/2007. Departemen Kementerian Pertanian. Jakarta.

Dinas Pertanian Tanaman Pangan Provinsi Jawa Barat, 2001. Kajian Pengembangan Pemasaran Model Pelelangan Komoditas Agribisnis Pada Sentra Produksi. Laporan Akhir Penelitian Kerjasama Penelitian dengan PT. Arjasari Primuraya, Bandung

Dinas Pertanian Tanaman Pangan Kabuapten Majalengka, 2000. Rencana Strategis Tahun 2001-2005. Kabupaten Majalengka

Fletcher, Keint L. 1987. The Law of Partnership. The Law Book Company Limited: Sidney.

Hafsah, Mohammad Jafar. 2003. Kemitraan Usaha: Konsepsi dan Strategi. Jakarta: Pustaka Sinar Harapan

Herawati, Augustin Rina. 2011. Sistem Kemitraan Usaha Mikro Kecil Menengah (UMKM) dan Usaha Besar dengan Pemodelan Systems Archetype. Jakarta: Universitas Indonesia.

Howard, N. (1996). "Negotiation as drama: how games become dramatic" International Negotiation Journal, Vol. $1,125-152$.

Lies Sulistyowati, Ronnie S. Natawidjaja, Zumi Saidah. 2013. Faktor-Faktor Sosial Ekonomi yang Mempengaruhi Keputusan 
Petani Mangga Terlibat dalam Sistem Informal dengan Pedagang Pengumpul. Bandung: Universitas Padjadjaran.

Linton, Ian. 1997. Kemitraan Meraih Keuntungan Bersama. Jakarta: Hailarang.

Moloeng, Lexy J. 2004. Metodologi Penelitian Kualitatif. Bandung: Remaja Rosdakarya.

Monica, Dina. 2006. Analisis Sosial Ekonomi Sistem Kemitraan Pengelolaan Wana Curug Nangka KPH Bogor Perum Perhutani Unit III Jawa Barat dan Banten. Skripsi. Bogor: Institut Pertanian Bogor.

Nasution. 2003. Metode Research. Jakarta : PT. Bumi Aksara.

Nazir, Moh. 2005. Metode Penelitian Edisi keenam. Bogor: Ghalia Indonesia.

Nurhayati. 2013. Analisis Kolaborasi Antar Pelaku dalam Rantai Pasok pada Klaster Cabai Merah (Capsicum annum L.). Jatinangor: Universitas Padjadjaran Nur Syamsiah, Lies Sulistyowati. 2014. "Kemitraan Usaha dalam Peningkatan Daya Saing dan Dampak Kebijakan Mangga di Kabupaten Cirebon, Jawa Barat." Seminar Nasional Pembangunan Inklusif di Sektor Pertanian. Jatinangor: Jurusan Agribisnis Universitas Padjadjaran.

Pracaya. 2004. Bertanam Mangga. Edisi Revisi. Jakarta: Penebar Swadaya

Prihatman, Kemal. 2000. Budidaya Pertanian Mangga (Mangifera Indica L).Jakarta: Deputi Menegristek Bidang Pendayagunaan dan Pemasyarakatan Ilmu Pengetahuan dan Teknologi.

Puspitasari, A. 2009. Pengaruh Kemitraan Terhadap Produktivitas Dan Pendapatan Petani Kakao. Skripsi. Departemen Agribisnis. Fakultas Ekonomi Dan Manajemen. Institut Pertanian Bogor.

Redfield, Robert. 1982. Masyarakat Petani dan Kebudayaan. Jakarta: CV Rajawali. Rochmawan, Sony. 2013. Pengaruh Pola Kemitraan dengan PT. BISI Terhadap
Pendapatan Petani Jagung di Kecamatan Banyakan Kabupaten Kediri. Jurnal Manajemen Agribisnis.

Rodjak, Abdul. 2006. Manajemen Usahatani. Bandung : Pustaka Giratuna.

Saptana, Arief Daryanto, Henry K. Daryanto, Kuntjoro. 2009. Strategi Kemitraan Usaha dalam Rangka Peningkatan Daya Saing Agribisnis Cabai Merah di Jawa Tengah. Bogor: Pusat Analisis Sosial Ekonomi dan Kebijakan Pertanian.

Saptana, Kurnia Suci Indraningsih, Endang L. Hastuti. 2007. Analisis Kelembagaan Kemitraan Usaha di Sentra Produksi Sayuran. Bogor: Pusat Analisis Sosial Ekonomi dan Kebijakan Pertanian.

Scott, James. C. 1981. Moral Ekonomi Petani. Jakarta: PT Intermasa.

Soekartawi, dkk. 1985. Ilmu Usahatani dan Penelitian Untuk Pengembangan Petani Kecil. Jakarta: Universitas Indonesia.

Sugiyono, 2011. Metode Penelitian Kuantitatif Kualitatif dan $R \& D$. Bandung: Alfabeta.

Suharsini, Arikunto. 2006. Prosedur Penelitian Suatu Pendekatan Praktik. Edisi Revisi VI. Jakarta: PT. Rineka Cipta.

Tika MP. 2008. Budaya Organisasi dan Peningkatan Kinerja Perusahaan. Jakarta:PT Bumi Aksara.

Usman, Rukiyati. 2013. Efektivitas Kemitraan Antara Koperasi dengan Kelompok Tani Penyuling Minyak Kayu Putih. Maluku Utara: Universitas Muhammadyah.

Veronica, Natalia. 2001. Formulasi Pola Kemitraan Agribisnis Pada PT. Agrobumi Puspa Sari dengan Petani Krisan. Skripsi. Bogor : Institut Pertanian Bogor.

Wahyuni., S dan R. Hendayana, 2001. Laporan Pengkajian Kinerja dan Arah Pengembangan BPP Jawa Timur. Badan Urusan Ketahanan Pangan- Pusat Penelitian dan Pengembangan Sosial Ekonomi Pertanian, Bogor 